\title{
Microbiological Characteristics and Nutritional Quality of Traditional Tchoukou Cheese from Niger
}

\section{Sabo Haoua Seini ${ }^{1 *}$, Alfa Keita ${ }^{1}$, Maazou Sani Mahaman Sabiou ${ }^{1}$, Aminou Illia Maman Nafiou $^{1}$, Bako Aminatou Maazou ${ }^{2}$, Hassimi Sadou ${ }^{1}$, Amoukou Ibrahim ${ }^{3}$,Ousmane Issa ${ }^{4}$, Mousbahou Malam Alma ${ }^{1}$, Ramatou Seini Sidikou ${ }^{5}$, Mahamane Saadou, Chanono Mogueza ${ }^{6}$ and Maman Sani Mahaman ${ }^{7}$}

${ }^{1}$ Department of Chemistry, Faculty of Science and Technology /Abdou Moumouni University of Niamey, Niger

${ }^{2}$ Department of Applied Biological Sciences, Faculty of Health Sciences /Abdou Moumouni University of Niamey, Niger

${ }^{3}$ Plant Production Department, Faculty of Agronomy, Abdou Moumouni University of Niamey ${ }^{4}$ Ministry of Livestock of Niger, Niger

${ }^{5}$ Department of Biology, Faculty of Science and Technology / Abdou Moumouni University of

Niamey, Niger

${ }^{6}$ Direction of the Experimental Station of Toukounous, Niger,

${ }^{7}$ Director of the Promotion of Subsidiaries and Quality at the Ministry of Livestock of Niger

*Corresponding author

\section{A B S T R A C T}

Keywords

Tchoukou, Quality, Microbiological,

Nutritional,

Improvement, Niger

Article Info

Accepted:

04 November 2018

Available Online:

10 December 2018
The method of making cheese, Tchoukou, in Niger has been the subject of several improvements, particularly in terms of hygiene, in order to increase producers' in comes. But, information on the microbiological and nutritional quality of Tchoukou is not fixed. Thus, this answer, microbiological analyzes of 13 samples and nutritional out of 7, from Filing are carried out. Microbiological analysis revealed poor general hygiene and faecal contamination on some samples. But its bacteriological quality is globally acceptable. These are specifically 2 satisfactory, 6 acceptable and 5 unsatisfactory samples. Tchoukou is particularly rich in protein (between 25.61 and 27.04\%) in fat (between 31.48 and 40.02\%), in calcium (between 898.14 and $1167.86 \mathrm{mg} / 100 \mathrm{~g}$ ) and in zinc (between 2.90 and $5.15 \mathrm{mg} / 100 \mathrm{~g}$ ). This gives a good nutritional quality, especially in zinc and calcium, which causes public health problems in Niger. However, from a microbiological point of view, additional efforts must be made to make this product more competitive at national and international level.

\section{Introduction}

Livestock farming, practiced all over the world, is the main activity that provides animal proteins through multiple animal productions such as meat, eggs, milk and products, including cheese. It is a major socioeconomic activity. Themilk (a nutritious and 
very perishable product) is the staple food for Nigerian farmers. Large quantities of milk are produced in the winter season causing huge losses. On the other hand, productions are insufficient in the dry season (AFCA Studies, 2013).

The losses are greater in pastoral systems because the fresh milk collection network is very weak or non-existent in the pastoral zone. This has led pastoralist women to develop strategies for processing this commodity to ensure the conservation of surplus produce. It concerns the production of butter, curd and home-made dry cheese called 'Tchoukou' in Hausa and Fulani and 'Tikomart' in Tamachek. This technique makes it possible to build up food reserves for the dry period. The sale of Tchoukousur plus also makes it possible to buy indispensable commodities for the family (JC Lambert and A. Soukehal, 1994).

In the agropastoral zone, unlike pastoral farming systems, dairy surpluses are valued in the form of dairy products (curd, cheese, butter, etc.) and sold on the markets (UEMOA, 2013).

The quality of the cheese is mainly influenced by its moisture content, $\mathrm{NaCl}, \mathrm{pH}$, moisture in non-fat substances (mainly the protein / moisture ratio) and the percentage of fat on dry matter (www.foodsafetycheese.com). For hard and hard cheeses such as tchoukou, the factors influencing their nutritional value are mainly the water content, the protein content, the fat content and the concentration of vitamins and minerals such as calcium (My cheese, www.metro.ca).

The cheese may contain food-degrading microorganisms or pathogenic microorganisms, which are present from the beginning in the milk used or are introduced at the later stages of cheese making, if sanitary and hygienic measures are not sufficient to prevent contamination during the transformation. The main pathogenic bacteria that represent a high risk for cheese safety are: Salmonella enterica, Listeria monocytogenes, Staphylococcus aureus and Enteropathogenic Escherichia coli (www.foodsafetycheese. com). Other parameters that affect microbial growth in cheese include aspects such as packaging type, storage time and temperature, and handling conditions. Johnson et al., (1990), Altekruse et al., (1998), Fontaine et al., (1980), Genigeorgis et al., (1991), quoted by GIUSEPPE Licitra (2010), showed that raw milk cheeses are no more dangerous than industrial cheeses made from pasteurized milk. To reduce the risk of contamination by these germs, the African Union has, in January 2011, a benchmark of good hygiene practices $(\mathrm{BPH})$ as a standard applicable on the African continent to support professionals of the agribusiness. This reference system aims at setting up the GHP and the Hazard Analysis Critical Control Point (HACCP) system (Table 2).

The evaluation of GHP is done by the Ishikawa method or "5M" method(Raw Material, Material, Method, Workforce and Medium).HACCP helps identify critical points for mastery; that is, the stages at which monitoring can be performed and is essential to prevent or eliminate a food safety hazard or reduce it to an acceptable level. Thetchoukou comes from empirical technologies. It is produced in often precarious conditions with poorly developed equipment (FAO, Food and Nutrition, www.FAO.org). In spite of the significant improvements that it has experienced, the manufacture of Tchoukou cheeses till retains an artisanal character in Niger. Information on the safety of this product is not specified (Lambert and Soukehal, 1994). Our choice is focused on the Urban Commune of Filingué where the production of Tchoukoucheese is the work of 
private producers. More specifically, the aim was to analyze the safety and nutritional quality of Tchoukoucheese.

\section{Materials and Methods}

\section{Animal material}

Chuku cheese is made from cow's milk in the study area

\section{Origin of samples}

They come from the villages of MakaniSouleymane, Toukounous station, GarinKimba and Tamagorgek (Figure 1), located in the municipality of Filingué, 178 $\mathrm{km}$ north-east of the capital Niamey.

\section{Methods}

\section{Sampling}

\section{For microbiological analyzes}

Germs in Tchoukou cheese can come from many sources : the milk, the material, the producer or the environment in which the processing takes place. Thus, $10 \%$ of the respondents were randomly selected, 13 samples. These samples were collected from six groups in three villages (Table 1).

\section{Sampling for physicochemical analyzes}

The nutrient content of Tchoukou depends on the manufacturing techniques. In the study area, the manufacturing methods are similar. The variation could come from the quality of the milk used; quality influenced by several factors including pastures and sanitary zoo situation. That is why the sample was reduced to $20 \%$ of the first sample (sample quadratic) or 3 samples. They were drawn at random in the three villages. Those are : M1, T4 and Tk1.During testing, there has been three test for each sample.

\section{Analytical methods in the laboratory}

Microbiological analyzes (NF EN ISO 4833, October 2013)

In the samples, the following microorganisms are sought: total mesophilic aerobic organisms, total and thermo-tolerant coliforms (E. coli), yeasts and molds, Staphylococcus aureus (S. aureus), Anaerobic sporedecreasing spores (ASR), Salmonella spp. faecal streptococci (group D of Lancefeld).

\section{Enumeration of total mesophilic aerobic} germs

The total flora is counted in sterile Petri dishes (BP) using PCA (Plate Count Agar) medium. Seeding consisted in depositing $1 \mathrm{ml}$ of the dilution in $15 \mathrm{ml}$ of PCA maintained at $45^{\circ} \mathrm{C}$. which was allowed to solidify before covering with $5 \mathrm{ml}$ of white agar. Incubation is at $37^{\circ}$ $\mathrm{C}$ for $22 \mathrm{~h}( \pm 2 h)$.

Enumeration of total and thermo-tolerant coliforms (E. coli)

The presumption is made on EPT (Buffered Peptide Water) broth at $37^{\circ} \mathrm{C}$ for 24 hours. Incubation of total coliforms is done at $37^{\circ} \mathrm{C}$ on Mac Conkey for $24 \mathrm{~h}$ and that of E. coli on EMB (Eosine Methylene Blue) medium at 44 - $\mathrm{C}$ for 24 h.the identification is made on gallery api $20 \mathrm{E}$ (E enterobacteria).

\section{Enumeration of yeasts and molds}

The dilution is done in EPT then transplanted on Sabouraud. Incubation is at $41^{\circ} \mathrm{C}$ for $24 \mathrm{~h}$.

Enumeration of Staphylococcus aureus ( $S$. aureus)

The dilution is done in EPT and then transplanted to Chapman. Incubation is made at $30{ }^{\circ} \mathrm{C}$ for $24 \mathrm{~h}$. The identification is made on gallery api 20 Staph (BIBLIO). 
Enumeration of Anaerobic Sulfito Spores Reducers (ASR)

Incubation is done on Meal Liver Agar Broth (GCF) maintained at $55^{\circ} \mathrm{C}$ for $24 \mathrm{~h}$ and then $48 \mathrm{~h}$ at $45^{\circ} \mathrm{C}( \pm 1)$. The number is expressed per $20 \mathrm{ml}$ of sample analyzed.

\section{Enumeration of Salmonella spp.}

Dilution is done in EPT.1 $\mathrm{ml}$ of the dilution is poured into $9 \mathrm{ml}$ of RVS (Vacilladis ratio) and incubated at $41^{\circ} \mathrm{C}$.The RVS is isolated on Hektoen and the identification is made on gallery api $20 \mathrm{E}$.

\section{Enumeration of faecal streptococci (Lancefeld group D)}

The incubation is carried out at $37^{\circ} \mathrm{C}$. for 24 hours on Roth broth then on BEA (Ball EsculinAzide) for 24 hours.germs are identified on Streptoapi gallery.

\section{Chemical analyzes}

The contents of water, ash, lipids, proteins are determined. The proportion of carbohydrates was calculated (Table 4).

\section{Determination of the content of water and volatile matter (Te)}

It corresponds to the loss of mass experienced by the sample after heating in an oven at $105^{\circ}$ $\mathrm{C}$ to constant weight. The content of water and of volatile matter are expressed in percentage by weight according to the formula:(AOAC, 1984)

$$
\mathrm{Te}=\frac{\mathrm{m} 1-\mathrm{m} 2}{\mathrm{m1}-\mathrm{m0}} \times 100
$$

Or:

$\mathrm{m} 0$ is the tare of the crucible (in g);

$\mathrm{m} 1$ is the mass of the crucible and the test portion before heating (in g); $\mathrm{m} 2$ is the mass of the crucible and the test sample after heating up to constant weight (in g).

The dry matter content (DM) of the sample, expressed as a percentage by weight, is deduced from the value of Te:

$$
\text { MS }=100-\mathrm{Te}=\frac{\mathrm{m} 2-\mathrm{m} 0}{\mathrm{~m} 1-\mathrm{m} 0} \times 100
$$

Determination of ash content (Tb) (AOAC, 1984)

It is determined by calcining the sample in an oven at $550 \pm 15^{\circ} \mathrm{C}$ to constant weight. The incineration residue obtained is a gray, clear and light powder.

The ash content in $\mathrm{g}$ per $100 \mathrm{~g}$ of dry product is calculated by the relationship :

$\%$ en cendres $=\mathrm{Ri} \times \frac{100}{\mathrm{Pe}} \times \frac{100}{100-\mathrm{H}}$

Ri: residue after incineration in g;

Pe: test sample of the wet sample in $\mathrm{g}$;

$\mathrm{H}$ : moisture of the sample in\% of the wet mass.

Determination of crude protein content (Tp) (Wolf, 1968)

The protein content is determined by calculation from the nitrogen assay according to the Kjeldahl method.1 $\mathrm{g}$ of sample packaged in Whatman filter paper (No. 1) is introduced into the flask. $10 \mathrm{ml}$ of concentrated sulfuric acid are added, followed by $0.5 \mathrm{~g}$ of the catalyst, containing sodium sulphate ( $\mathrm{Na} 2$ SO 4), copper sulphate (CuSO 4) and selenium oxide ( $\mathrm{SeO} 2)$ in the ratio of 10: 5 : $01(\mathrm{~g} / \mathrm{g} / \mathrm{g})$. The flask is then placed in a Kjeldhal digestion apparatus for 2 hours at $400{ }^{\circ} \mathrm{C}$. until a light green liquid is obtained. The dig estat is cooled, then $30 \mathrm{ml}$ of distilled water are added. The flask is placed in a distiller e Kjeldahl, then $50 \mathrm{ml}$ of a sodium 
hydroxide solution $40 \%$. The distillate is recovered in a beaker containing $25 \mathrm{ml}$ of a mixture of colored indicators in solution in boric acid $4 \%$.About $140 \mathrm{ml}$ of distillate are collected and then titrated with $0.02 \mathrm{~N}$ sulfuric acid until the indicator turns. A reactive white is produced under the same conditions.

\section{$T p=6.38 \times \frac{(V 1-V 0) \times C \times 14 \times 100}{1000 \times P e}$ $1000 \times \mathrm{Pe}$ \\ Or:}

$\mathrm{V} 1$ = volume of the sulfuric acid solution used for the test portion (in $\mathrm{mL}$ );

$\mathrm{V} 0=$ volume of the sulfuric acid solution used for the blank test (in $\mathrm{mL}$ );

$\mathrm{C}=$ concentration of the sulfuric acid solution (in $\mathrm{mol} / \mathrm{L}$ );

$6.38=$ conversion coefficient of nitrogen into protein for dairy products;

$\mathrm{Pe}=$ mass of the test sample (in $\mathrm{g}$ ).

\section{Determination of total lipid content (TL)} (IUPAC, 1968)

The lipids are extracted with soxhlet by percolation of hexane for 6 hours. After extraction, the solvent is evaporated in a rotary evaporator. The flask is placed in an oven at $105^{\circ} \mathrm{C}$. for 1 hour to remove traces of the solvent and then cooled with the desiccator. The balloon is weighed to constant weight.

The lipid content TL in g per $100 \mathrm{~g}$ of dry product is calculated according to the following formula:

\section{$\%$ en lipides $=\mathrm{m} \times \frac{100}{\mathrm{Pe}} \times \frac{100}{100-\mathrm{H}}$}

Or

$\mathrm{m}$ : mass in $\mathrm{g}$ of the lipid residue; Pe: mass in $\mathrm{g}$ of the test sample;
$\mathrm{H}$ : water content of the sample in $\%$ of the wet mass.

\section{Determination of total carbohydrates}

The total carbohydrate content "G" in g per $100 \mathrm{~g}$ of product is calculated by difference:

$\mathbf{G}=\mathbf{1 0 0}-(\mathbf{H}+\mathbf{C}+\mathbf{P}+\mathbf{L}), \mathrm{H}:$ moisture content; $\mathrm{C}$ : ash content; $\mathrm{P}$ : total protein content;

L: total lipid content

Determination of the content of certain minerals: (AOAC, 1990)

\section{Mineralization and preparation of the extract}

About $1 \mathrm{~g}$ of the finely ground mill contained in a platinum capsule is incinerated in the oven at $600 \circ \mathrm{C}$ for 2 hours. The ashes obtained, generally clear, are taken up with approximately $1 \mathrm{ml}$ of distilled water and $3 \mathrm{ml}$ of $50 \%$ hydrochloric acid.This step is followed by the evaporation of these solvents on hot plates to $40 \%$ until complete drying. The residue obtained is once again moistened with $3 \mathrm{ml}$ of $50 \%$ hydrochloric acid and a little distilled water, then filtered on filter paper (qualitative Toyo with $11 \mathrm{~cm}$ diameter) in a $100 \mathrm{ml}$ flask. The crucible is rinsed 3 times with distilled water and the flask is made up to $100 \mathrm{ml}$ still with distilled water. This extract will serve as the mother solution for the dosages that will follow.

\section{Determination of mineral elements}

\section{Principle}

A non-excited metal atom receiving light radiation of its characteristic wavelength absorbs it to the excited state.The metal atoms are obtained by direct vaporization of the solution of the studied body in a flame of an air-acetylene torch. 


\section{Operating mode}

For each metal, we used a lamp whose cathode is made of this metal.The standard solutions and optimal range for each element are as follows:

$\mathrm{Zn}$ : standard range: $0.5,1,2,4.5 \mathrm{ppm} . \mathrm{Zn}: \lambda=$ 213.9; Slit $=0.7$;lamp: $15 \mathrm{~mA}$.

$\mathrm{Ca}$ and $\mathrm{Mg}$ : standard range: $0.5,1,2,5,10$ ppm.Ca: $\lambda=422.7$;Slit $=0.7$;lamp: 12 mA.Mg: $\lambda=285.7$;Slit $=0.7$;lamp: $10 \mathrm{~mA}$.

$\mathrm{Na}$ and $\mathrm{K}$ : standard range: $0.5,1,2,5$ ppm.Na: $\lambda=589 ;$ Slit $=0.7 . \mathrm{K}: \lambda=766.5 ;$ Slit $=0.7$.

Dilutions are necessary for some samples, especially $\mathrm{Ca}, \mathrm{Mg}, \mathrm{Na}$ and $\mathrm{K} . \mathrm{Zn}$ no dilution was performed. The value read on the device is absorbance. The content of each element is calculated according to the following formula.

Teneur en $\mathrm{mg} / 100 \mathrm{~g}=\frac{\text { valeur en } \mathrm{ppm} \times \mathrm{V} \times \mathbf{f} \times 0,1}{\mathrm{P}}$

Or

$\mathrm{F}$ : dilution factor; $\mathrm{P}$ : test sample in $\mathrm{g}$; $\mathrm{V}$ : volume of the extract; Value in $\mathrm{ppm}=$ value obtained on the calibration curve

Statistical analysis was done with the Sphinx1 4.5 software.

\section{Results and Discussion}

Identification of contaminations using the "5 M" method

\section{Collection of milk (raw material)}

Milking is done outdoors in the study area.In the producers, it is done manually and the milk is collected in calabashes before being transferred into plastic containers. At the
Toukounous Station, the milk is directly harvested in stainless steel buckets by specialized milkers.Before coagulation, the milk is filtered to rid it of certain impurities.

\section{Hygiene of personnel (labor and material)}

All women producers reported having benefited from hygiene training funded by the 'MADARA' project of Mercy Corps.The modules developed include milking hygiene, personal hygiene and equipment hygiene. Regarding the staff, the producers respect the principles of personal hygiene. But they are not subject to any medical control and do not have protective equipment (workwear, headdress, bucco nasal mask, gloves, etc.).

The materials put in place are easy to wash (plastic and stainless steel).According to the producers, the materials are washed with soap before and after each use (Photo 10).

Tchoukou Manufacturing (Method and Medium)

Apart from the AFPEN-Wéli group which has a room (in poor condition), the tchoukou is made at home.We had observed that the producers swept the square before the start of the operation.

The tchoukou is sometimes made in the open air, sometimes under a shed.Drying takes place $100 \%$ in the open air.Storage is in plastic buckets and cartons covered with a clean cloth to allow aeration.At the time of sale, the tchoukou is packed in sachets.

\section{P Application laughed ncipe mastery theory of health risks (HACCP) in the manufacturing process tchoukou}

The present study note that some manufacturing steps require control to prevent the introduction or development of hazards. 


\section{Results of the analysis}

\section{Microbiological properties of tchoukou}

The analyzes focused on the main microbiological criteria cited by Pierre Viet (1989).The results show three levels of appreciation : Satisfactory, Acceptable and Unsatisfactory (Table 3). Some samples are characterized by poor general hygienic condition ; others are witnesses of a stain of faecal origin (contamination index).

No sample is of unacceptable quality because salmonella and ASR are absent everywhere. Overall, the bacteriological quality of the tchoukou is acceptable. The conclusions are based on the evaluation grid of the Pasteur Institute of Cote d'Ivoire.

\section{Nutritional quality}

The dates of manufacture are not the same. Sample T4 is manufactured one day after the other two ; this explains its high water content.The average levels of proteins, lipids, carbohydrates and ashes are respectively : 29,$01 ; 40,19 ; 28.20$ and $2.60 \%$.

\section{Mineral content}

Cheese, tchoukou contains moderately 4.25 $\mathrm{mg} / 100 \mathrm{~g}$ of zinc, $82.09 \mathrm{mg} / 100 \mathrm{~g}$ of magnesium, $8.05 \mathrm{mg} / 100 \mathrm{~g}$ of sodium, $713.14 \mathrm{mg} / 100 \mathrm{~g}$ of potassium and 1063.04 $\mathrm{mg} / 100 \mathrm{~g}$ of calcium (Table 5).

Table.1 Samples subjected to microbiological analyzes

\begin{tabular}{|l|l|l|}
\hline \multirow{2}{*}{ Town } & \multicolumn{2}{|c|}{ Sample } \\
\cline { 2 - 3 } & Number & Identification \\
\hline Makani & 5 & $\mathrm{M} 1 ; \mathrm{M} 2 ; \mathrm{M} 3 ; \mathrm{M} 4 ; \mathrm{M} 5$. \\
\hline Tamagorgek & 4 & $\mathrm{~T} 1 ; \mathrm{T} 2 ; \mathrm{T} 3 ; \mathrm{T} 4$. \\
\hline Toukounous Station & 4 & tk1 $; \mathrm{Tk} 2 ; \mathrm{tk} 3 ; \mathrm{TK} 4$. \\
\hline Total & 13 & 13 \\
\hline
\end{tabular}

Table.2 HACCP analysis of the manufacture of the tchoukou

\begin{tabular}{|l|l|l|l|}
\hline NOT & Description of the stage & Action & Associatedrisk \\
\hline $\mathbf{1}$ & Collection of milk & Status quo & Introduction of danger \\
\hline $\mathbf{2}$ & Filtration & Elimination of danger & Non elimination of danger \\
\hline $\mathbf{3}$ & Coagulation & Status quo & Development of danger \\
\hline $\mathbf{4}$ & Cast-draining & Status quo & Introduction of danger \\
\hline $\mathbf{5}$ & Drying & Elimination of danger & Introduction of danger \\
\hline $\mathbf{6}$ & Storage and Conservation & Status quo & Development of danger \\
\hline
\end{tabular}


Table.3 Microbiological Quality of tchoukou

\begin{tabular}{|c|c|c|c|c|c|c|c|c|c|c|}
\hline \multirow[b]{2}{*}{ NOT } & \multirow[b]{2}{*}{ Ec } & \multicolumn{8}{|c|}{ seeds } & \multirow[b]{2}{*}{ Quality } \\
\hline & & $\begin{array}{l}\text { GAM30 } \\
\mathrm{C} / \mathrm{g}\end{array}$ & $\begin{array}{l}\text { CT30 } \\
\text { C/g }\end{array}$ & $\begin{array}{l}\text { EC44 } \\
\text { C/g }\end{array}$ & $\begin{array}{l}\mathrm{LM} \\
37^{\circ} \mathrm{C} / \mathrm{g}\end{array}$ & $\begin{array}{l}\text { S. At37 } \\
\text { C/g }\end{array}$ & $\begin{array}{l}\text { ASR } \\
46^{\circ} \mathrm{C} / \mathrm{g}\end{array}$ & $\begin{array}{l}\mathrm{S} \\
37^{\circ} \mathrm{C} / 25 \mathrm{~g}\end{array}$ & $\begin{array}{l}\text { S.D. } 37^{\circ} \\
\text { C/g }\end{array}$ & \\
\hline 1 & T1 & $>10^{4}$ & $>10^{4}$ & $<10^{2}$ & 00 & 00 & 00 & Absence & $<10^{4}$ & Acceptable \\
\hline 2 & $\mathrm{~T} 2$ & $>10^{4}$ & $>10^{4}$ & $<10^{2}$ & $>10^{2}$ & $<10^{2}$ & 00 & Absence & $>10^{4}$ & Acceptable \\
\hline 3 & T3 & $>10^{4}$ & $>10^{4}$ & $>10^{2}$ & $>10^{2}$ & $>10^{2}$ & 00 & Absence & $>10^{4}$ & Unsatisfactory \\
\hline 4 & $\mathrm{~T} 4$ & $>10^{4}$ & $>10^{4}$ & $>10^{2}$ & 00 & 00 & 00 & Absence & $>10^{4}$ & Unsatisfactory \\
\hline 5 & tk1 & $>10^{4}$ & $<10^{4}$ & $<10^{2}$ & $<10^{2}$ & 00 & 00 & Absence & $>10^{4}$ & Acceptable \\
\hline 6 & Tk2 & $>10^{4}$ & $>10^{4}$ & $>10^{2}$ & $<10^{2}$ & $<10^{2}$ & 00 & Absence & $<10^{4}$ & Acceptable \\
\hline 7 & tk3 & $>10^{4}$ & $<10^{4}$ & $<10^{2}$ & $<10^{2}$ & 00 & 00 & Absence & $<10^{4}$ & satisfactory \\
\hline 8 & TK4 & $>10^{4}$ & $>10^{4}$ & $>10^{2}$ & $>10^{2}$ & $<10^{2}$ & 00 & Absence & $>10^{4}$ & Unsatisfactory \\
\hline 9 & M1 & $>10^{4}$ & $>10^{4}$ & $>10^{2}$ & $>10^{2}$ & 00 & 00 & Absence & $>10^{4}$ & Unsatisfactory \\
\hline 10 & M2 & $>10^{4}$ & $>10^{4}$ & $>10^{2}$ & 00 & 00 & 00 & Absence & $>10^{4}$ & Unsatisfactory \\
\hline 11 & M3 & $>10^{4}$ & $>10^{4}$ & $<10^{2}$ & 00 & 00 & 00 & Absence & $<10^{4}$ & Acceptable \\
\hline 12 & M4 & $<10^{4}$ & $<10^{4}$ & 00 & $>10^{2}$ & 00 & 00 & Absence & $>10^{4}$ & satisfactory \\
\hline 13 & M5 & $>10^{4}$ & $<10^{4}$ & $<10^{2}$ & $>10^{2}$ & 00 & 00 & Absence & $>10^{4}$ & Acceptable \\
\hline
\end{tabular}

GAM : MesophilicAerobicBacteria, Ec Sample, E c : E. coli, LM : yeasts and molds, SA : Staphylococci aureus, Anaerobic spore sulphite (ASR), S : Salmonella spp, SD : Fecalstreptococci (group D of Lancefeld

Table.4 Composition of Choukou T

\begin{tabular}{|l|l|l|l|l|l|}
\hline \multirow{2}{*}{ Sample } & \multicolumn{5}{l|}{ Content in $\mathrm{g}$ per $100 \mathrm{~g}$ dry matter $(\mathrm{ms})$} \\
\cline { 2 - 7 } & Humidity & protein & lipids & carbohydrates & Ashes \\
\hline T4 & $3.36 \pm 0.23$ & $30.21 \pm 0.42$ & 40.43 & 26.69 & $2.67 \pm 0.10$ \\
\hline M1 & $2.11 \pm 0.07$ & $26.72 \pm 0.91$ & 43.67 & 26.59 & $3.02 \pm 0.01$ \\
\hline tk1 & $2.92 \pm 0.09$ & $30.09 \pm 0.16$ & 36.46 & 31,32 & $2.12 \pm 0.06$ \\
\hline Average & 2.80 & 29,01 & 40,19 & 28,20 & 2.60 \\
\hline
\end{tabular}

Table.5 Mineral Content of tchoukou

\begin{tabular}{|l|l|l|l|l|l|}
\hline \multirow{2}{*}{ Sample } & \multicolumn{6}{|l|}{ Content in mg per 100 g of defatted dry matter } \\
\cline { 2 - 6 } & Zinc & Magnesium & Sodium & Potassium & Calcium \\
\hline TD & $5.15 \pm 0.51$ & $80.58 \pm 1.05$ & $6.94 \pm 0.28$ & $808.23 \pm 7.19$ & $1123.13 \pm 1.66$ \\
\hline MY & $2.90 \pm 0.13$ & $83.14 \pm 3.39$ & $7.39 \pm 0.22$ & $622.47 \pm 9.52$ & $898.14 \pm 4.25$ \\
\hline TKA & $4.69 \pm 0.24$ & $82.56 \pm 1.29$ & $9.83 \pm 0.15$ & $708.73 \pm 1.55$ & $1167.86 \pm 4.69$ \\
\hline Average & 4.25 & 82.09 & 8.05 & 713.14 & 1063.04 \\
\hline
\end{tabular}

Table.6 Nutrient values of some foodstuffs of animal origin.

\begin{tabular}{|c|c|c|c|c|c|c|c|}
\hline \multirow[t]{2}{*}{ Nutrients } & \multirow[t]{2}{*}{ units } & \multicolumn{6}{|c|}{ Content per $100 \mathrm{~g}$ of food } \\
\hline & & tchoukou & $\begin{array}{l}\text { Peul cheese } \\
\text { (Wagashi) }\end{array}$ & Beef & Henegg & Fish & Wholemilk \\
\hline Water & G & 2.8 & 40 & 63 & 77 & 70 & 85 \\
\hline Fat & $\mathrm{G}$ & 40,19 & 30 & 18 & 10 & 10 & 5 \\
\hline Protein & $\mathrm{G}$ & 29 & 24 & 18 & 12 & 19 & 4 \\
\hline Calcium & $\mathrm{mg}$ & 1063 & 1200 & 11 & 45 & 30 & 143 \\
\hline
\end{tabular}


Photo.1 Soap wash of the drying tray (Toukounous)

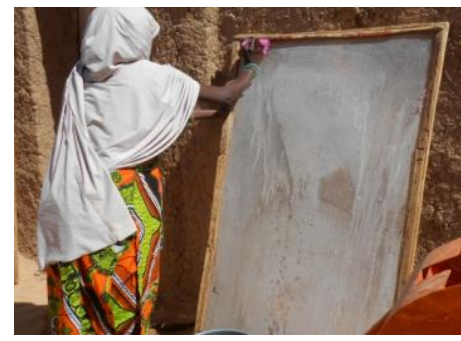

Figure.1 Location of the study area (Source: Our study)

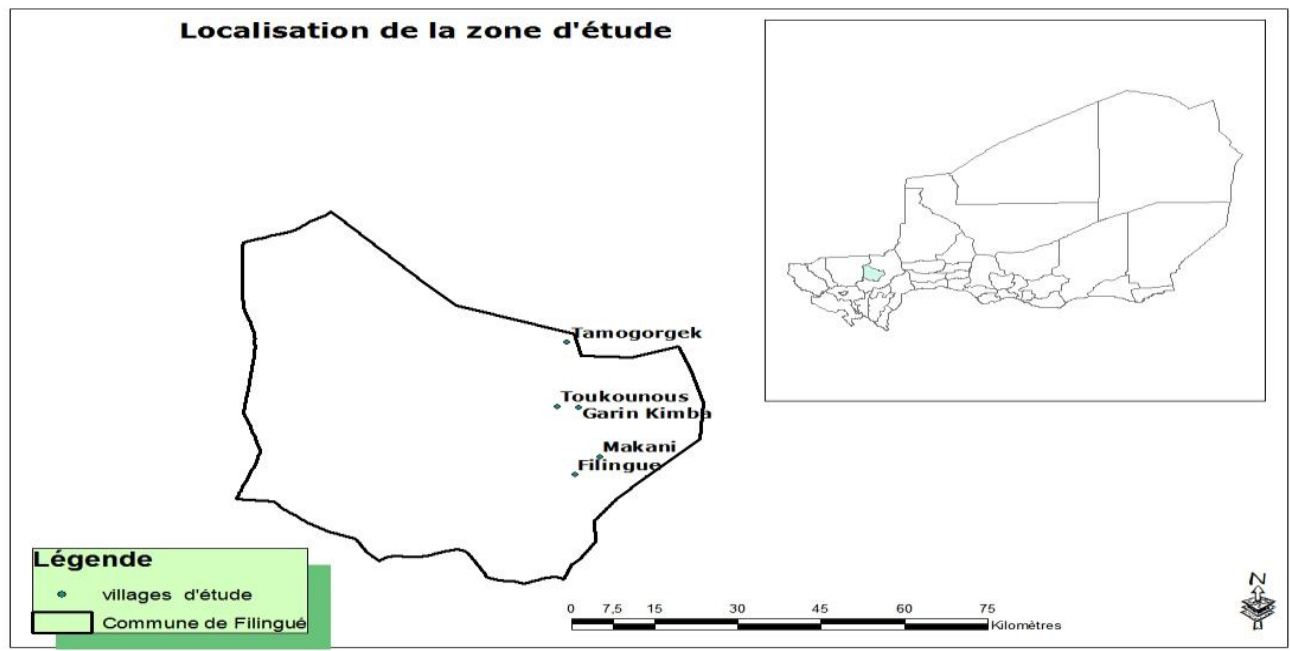

According to Pierre Veit (1989), the main microbiological criteria are :

Aerobic germs at $30^{\circ} \mathrm{C}$ or " total mesophilic flora " that inform the amount of bacteria present in the food;

Total coliforms at $30^{\circ} \mathrm{C}:$ a high number of these coliforms characterizes a poor general hygienic state ;

Faecal coliforms (E. coli) at $45^{\circ} \mathrm{C}( \pm$ 1).Their presence in the food is a witness of a stain of fecal origin.They are a good indicator of contamination. The food is of satisfactory quality if it contains less than $10{ }^{4} \mathrm{CFU} /$ g.It presents a risk to human health (unacceptable quality) beyond $10{ }^{5} \mathrm{CFU} / \mathrm{g}$ (Grand-Ducal legislation, Ministerial Regulation of 10 August 1995 on dairy products);
Sulphito-reducing anaerobes (ASR) at $46{ }^{\circ} \mathrm{C}$. Clostridium perfringens is the main species.It is very dangerous for humans and is frequently implicated in food poisoning in catering.He witnesses the non-respect of the conservation rules. Only a small number is tolerated $\left(10^{2} \mathrm{CFU} / \mathrm{g}\right)$;

Staphylococcus aureus : responsible for collective foodborne illness (TIAC).They must be absent from foods or present in very small quantities. The food is of satisfactory quality if it contains less than $10{ }^{4} \mathrm{CFU} / \mathrm{g}$ and is unacceptable above $10^{5} \mathrm{CFU} / \mathrm{g}$ (Regulation 2073/2005 / EC) ;

Salmonella (Salmonella entereritidis) : considering their pathogenic capacity, their absence is required in $25 \mathrm{~g}$ of food (Regulation 2073/2005 / EC) ; 
Yeasts and molds : a high number of molds can reveal a health problem by making suspect the presence of mycotoxins. Yeasts mean more an alteration problem.

\section{Sanitary and hygienic qualities}

The results show that the Filigreed tchoukou is produced by hand. The manufacturing process involves stages of introduction, development and elimination of hazards. The lack of adequate equipment does not fully guarantee the hygienic safety of tchoukou despite the training of staff. But the results show that the bacteriological quality of Filigated Tchoukou is generally acceptable, making it a safe food. This is confirmed by Giuseppe licitra (2010) who said that women in many countries produce safe food while they have access to virtually no technology. The present study quotes is a complex set of factors that makes them safe.Most of the time, it is a synergy of actions that prevents the appearance of micro-bacteria in cheeses based on raw milk, in particular bacteriostatic and / or bactericidal actions: antimicrobial activity of raw milk, $\mathrm{pH}$, temperature, change the concentration of salt and sugar during manufacture, final concentration of salt, moisture content, amino acids and free fatty acids in the finished product ".

The miracle of the quality of craft products in developing countries caught the attention of researchers at the International Seminar on Women Producers of Cheese held in April 2007 at CoRFiLaC, a research center on dairy products in Ragusa, Italy. The challenge was to seek to understand technologically and scientifically the processes that make these cheeses safe. Giuseppe Licitra cites as examples of safe cheeses " in Benin, the Peul ethnic group produces cheese wagashi. They use the latex of Calotropisprocera to coagulate the milk and produce a cheese with low proteolytic activity, which allows them to boil and reboil every other day and keep it for about a month after production. This simple, long-term heat treatment makes cheese a safe food. Another possibility is to dry it in the sun to extend its conservation time. This technique of drying in the sun is also used in Morocco for making Lakila, in Burkina Faso for Gapal, in Mali for Gashi and in Niger for Tchoukou.

\section{Nutritional value of tchoukou}

Like all cheeses, tchoukou contains essential nutrients for the body. Its low water content (2.8\%) makes it contain nutrients in higher proportions. The comparison with the results of Kees (1996) (in Benin) on Wagashi and some animal foods commonly consumed, allows us to assert the superiority of the nutritional value of tchoukou (Table 6).

The protein content of tchoukou is higher than that of wagashi, beef, egg, fish and whole milk. It is the same for fat. Overall, tchoukou is more nutritious than wagashi, beef, egg and fish.

The average protein content of the tchoukou is $29 \%$ of the MS. It is classified as hard and hard cheese with a protein content of 22 to 30\% (My Cheesemaker, www.metro.ca) .These proteins have a biological value comparable to that of meat (18 to 20\%) and have a better balance in essential amino acids (FAO, Nutritional Value of Cheese, www.FAO.org) .Philippe PATUREAU (2003) has fixed the recommended nutritional intake (ANC) protein at $0.8 \mathrm{mg} / \mathrm{kg} /$ day. Three sheets of tchoukou alone would cover the protein requirements of an adult weighing $50 \mathrm{~kg}$ of body weight. Proteins are the main structural components of cells and tissues of the body. They are necessary for the growth and development of the body, the maintenance and repair and replacement of damaged tissues, the production of metabolic and digestive enzymes, and they are essential 
components of certain hormones (FAO, Food and human nutrition, www.FAO.org).

The high fat content (40.19\% DM) gives the tchoukou its special organoleptic qualities. Lipids are responsible for the texture and flavor of the tchoukou. They are indeed responsible for the lubrication, the creamy mouth feel, the flavor and it also affects its firmness (My cheese,www.metro.ca) .They play different roles in the body, including " fuel" to meet the energy needs of cells. They solubilize and transport the fat-soluble vitamins - A, D, E and K - in the body.

Tchoukou is an important source of calcium with an average grade of $1063 \mathrm{mg}$ per $100 \mathrm{~g}$ of defatted MS. Inspired by the Clinical Nutrition Manual, Professional Corporation of Dietitians, it covers the needs of children (500 to $800 \mathrm{mg} /$ day) and women aged 19 to 49 (1000 mg / day).It is almost enough for teens and women aged 50 and over (1300 mg / day).Calcium is very important for health.It is involved in the formation and strength of bones and teeth, the fight against osteoporosis in adults, the regulation of heart rhythm and the coagulation of blood.It would help maintain or lose weight (My Cheesemaker, www.metro.ca) .

In addition to consumption of tchoukou, the consumption of whey provides a lot of nutrients. According to the FAO (1991), the nutritional quality of whey is due to the presence of both lactose and serum proteins (20\% of milk proteins).The functional properties related to serum proteins make them interesting products both for the feeding of livestock, but also in human nutrition. These proteins are used in infant feeding for their nutritional qualities (richness in essential amino acids), for the preparation of cooked meals (water retention), for their solubility at any $\mathrm{pH}$ scale (milk drinks, lemonade) and for their foaming power (confectionery, nougaty).The whey recovered for human or animal nutrition comes mainly from cheese making.

In conclusion, Tchoukou cheese production is a dynamic sector of activity in the urban district of Filingué. It is consumed by both rural people and towns (Filingué, Niamey, etc.).Producers use the same technology for making tchoukou cheese.

The analyzes showed that tchoukou cheese is of acceptable hygienic quality.

The nutritional quality shows teneurs interesting protein, zinc and calcium. The consumption of tchoukou cheese can help to fight against protein, zinc and calcium deficiencies that pose public health problems in Niger. Despite these qualities, the production of cheese tchoukou requires improvement, particularly through the establishment of an efficient control of the safety system, as the raw material milk is a product easily alterable.

\section{References}

Association of Official Analytical Chemist (AOAC).1984. Official Method of Analysis Edit.AOAC; Whahsington DC.P24003.

Association of Official Analytical Chemist (AOAC).1990. Official Method of Analysis Edit AOAC; Whahsington DC;No. 945.16, No. 975.03.

Association of Official Analytical Chemist (AOAC) 1984.Official Method of Analysis Edit. AOAC; Whahsington DC.P14006.

Africa Cabinet Council and Accompaniment (AFCA) of Niger.2012.Study on the Improvement of Production Technology and Conservation of Dry Cheese (Tchoukou) in Niger, Final Report, 79p. 
CESAO-PRN, 2015. Study report of the added value chains of the "Milk" sector in the MADARA / Filingue project area.36p.

FAO, 200 7. Control of health risks in a process of transformation.Presentation ppt, training course of MAP (France), Ouagadougou.14 slides.

FAO / WHO, 2000. Report of the Fourth Session of the Codex Committee on Milk and Milk Products.Wellington (New Zealand).84p.

GIUSEPPE LICITRA, 2010. Women and traditional cheeses in developing countries: the issue of food security.Ocha Colloquium "Cultures of the Milks of the World", Paris.2p.

Government of the Grand Duchy of Luxembourg, 2015. Microbiological criteria for foodstuffs.Guidelines for interpretation. 59 p.

http://www.memoireonline.com/04/10/3418/1 ait-et-fromage-au-Benin.html accessed 19 September 2015 at $17 \mathrm{~h}: 20$;

International Union for Pure and Applied Chemistry (IUPAC).(1968).Analytical methodsunified by the fat section of the International Union of PureApplied Chemistry, IB 2.

JC Lambert and A. Soukehal, 1994.Improvement of Chukuo cheese technology in Niger.FAO Food and Nutrition Column No. 28 ISBN 92-520534-6.17p.

NOMEL Meleme Sandrine DA, 2015. Contribution to improving the sanitary quality of street food: the case of the communes of Yopougon and Adjame (Abidjan-Cote d'Ivoire).Mémoire masters in food and nutritional security.Agrhymet Regional Center of Niamey.75p.

NF EN ISO 4833. 2013. Horizontal Method for Enumeration of Microorganisms, Part 1.Microbiology of Foods.

Pierre Veit, 1989. Microbiological Criteria for Food.Quality option $N^{\circ} 67$ and $N^{\circ}$ $68.23 \mathrm{p}$.

University of Abomey-Calavi, 2006. Production and processing of fresh milk into Fulani cheese in Benin : guide of good practices.Version validated during the national workshop of July 14, 2006. Faculty of Agricultural Sciences.33p.

Webography

WOLF J. -P.(1968) Manual of analysis of fatty substances: Protein matters.Edit.AZOULAYE.P552.

www.foodsafetycheese.com Chapter 5: Characteristics of cheese, $13 \mathrm{p}$.

\section{How to cite this article:}

Sabo Haoua Seini, Alfa Keita, Maazou Sani Mahaman Sabiou, Aminou Illia Maman Nafiou, Bako Aminatou Maazou, Hassimi Sadou, Amoukou Ibrahim, Ousmane Issa, Mousbahou Malam Alma, Ramatou Seini Sidikou, Mahamane Saadou, Chanono Mogueza and Maman Sani Mahaman. 2018. Microbiological Characteristics and Nutritional Quality of Traditional Tchoukou Cheese from Niger. Int.J.Curr.Microbiol.App.Sci. 7(12): 317-328. doi: https://doi.org/10.20546/ijcmas.2018.712.039 